\title{
0.Т. Азімов
}

\section{СТВОРЕННЯ УЗАГАЛЬНЕНОЇ ТЕХНОЛОГІЧНОЇ СХЕМИ ПЕРЕТВОРЕННЯ, ДЕШИФРУВАННЯ I ТЕМАТИЧНО ̈ ІНТЕРПРЕТАЦІЇ ДАНИХ ДИСТАНЦІЙНИХ ЗНІМАНЬ ПРИ ВИРІШЕННІ ГЕОЛОГІЧНИХ ЗАВДАНЬ}

\author{
0. T. Azimov
}

\section{GENERATION OF THE GENERIC FLOWCHART OF TRANSFORMATION, DECODING AND THEMATIC INTERPRETATION OF REMOTE SENSING DATA FOR GEOLOGIC OBJECTIVES SOLVING}

\author{
Охарактеризовано розроблену концептуальну узагальнену технологічну модульну схему оброблення, дешифрування і \\ геологічної інтерпретації матеріалів аерокосмічних знімань у комплексі з даними геолого-геофізичних досліджень на \\ підставі використання геоінформаційних технологій. \\ Ключові слова: технологічна схема, геоінформаційні технології, просторово розподілені дані.
}

Охарактеризована разработанная концептуальная обобщенная технологическая модульная схема обработки, дешифрирования и геологической интерпретации материалов аэрокосмических съемок в комплексе с данными геологогеофизических исследований на основе использования геоинформационных технологий.

Ключевые слова: технологическая схема, геоинформационные технологии, пространственно распределенные данные.

The designed conceptual generic modular flowchart of transformation, decoding and geologic interpretation of remote sensing data in the complex with geological and geophysical data is characterised. The flowchart is based on geoinformation technologies application.

Keywords: flowchart, geoinformation technologies, spatial data.

\section{ФОРМУВАННЯ МЕТИ ТА ЗАВДАНЬ РОБОТИ}

Традиційна методика використання даних дистанційного зондування Землі (ДЗЗ) під час геологорозвідувальних робіт (ГРР) $[9,13,17,18$, 20 та ін.] зазвичай передбачала таку технологічну послідовність: збір необхідних архівних і замовлених матеріалів аерокосмічних зйомок (МАКЗ); проблемно орієнтований аналіз і обробка МАКЗ, результатом яких $€$ створення дистанційної основи тієї чи іншої геологічної карти; тематичне дешифрування дистанційної основи; інтерпретація схем дешифрування; складання тематичних карт і схем 3 легендами або умовними позначеннями; подання й зберігання вказаних карт і схем. При цьому чинник впровадження комп'ютерних технологій обробки/інтерпретації даних мав незначний рівень. В останній час $з$ широким розвитком геоінформатики - науки, технології й виробничої діяльності, що застосовує теорію, методи і засоби накопичення, оброблення i передачі різноманітних даних, інформації та знань про Землю з допомогою електроннообчислювальних машин, комп'ютерів та інших технічних розробок - при ГРР все ширше використовуються її (геоінформатики) досягнен- ня. Це властиве й аерокосмогеологічним дослідженням (АКГД), результатами яких [1, 10, 12, 15, 19 та ін.] загалом визначено концепцію і розроблено низку технологічних схем перетворення/інтерпретації даних ДЗ3, здебільшого при реалізації конкретних тематичних розробок, зокрема під час нафтогазопошукових робіт.

Разом з тим вирішення проблеми впровадження геоінформаційних технологій у практику дистанційних методів вивчення геологічної будови територій висуває ряд як наукових, так і суто технічних завдань. Насамперед не розроблено загальноприйняту концепцію i не створено універсальну технологічну схему оброблення, дешифрування і геологічної інтерпретації матеріалів дистанційних зйомок (МД3) на підставі застосування комп'ютерних засобів і програм. Дослідження у цій сфері тривають. Отже, метою цієї статті є розгляд запропонованої автором концепції створення узагальненої схеми обробки/інтерпретації МАКЗ із залученням геоінформаційних технологій при ГРР, а також основних складових цієї схеми. Новизна розробки полягає саме у тому, що схема порівняно $з$ попередніми

(C) О.Т. Азімов, 2011 
аналогами має узагальнювальний характер під час виконання АКГД найрізноманітнішого спрямування, а не суто вузькотематичного.

\section{ВИКЛАДЕННЯ ОСНОВНОГО МАТЕРІАЛУ ДОСЛІДЖЕНЬ ТА ОТРИМАНИХ НАУКОВИХ РЕЗУЛЬТАТІВ}

Автор протягом ряду років вивчав диз'юнктивні структури, пов'язані з ними процеси та інші геологічні об'єкти (зокрема, поклади вуглеводнів, рудні тіла тощо) з дотриманням визнаних теоретико-методологічних засад проведення АКГД, технологічної послідовності використання даних Д3З. Враховуючи й узагальнюючи відомі комп'ютеризовані методи, методичні підходи і прийоми роботи з комплексом МАКЗ і апріорними результатами геолого-геофізичних робіт, а також основні етапи їх виконання і послідовність відповідних операцій, нами розроблено [2-8] концептуальну узагальнену технологічну модульну схему перетворення, дешифрування і геологічної інтерпретації даних дзз на підставі використання геоінформаційних технологій з метою виявлення i визначення характеристик диз'юнктивних дислокацій земної кори (див. рисунок). Ця схема реалізується у своєрідній геоінформаційній системі, основними складовими якої $€$ база знань (БЗ), база даних (БД) і програмне забезпечення, що призначене для управління БД і тематичною обробкою даних. Подібних підходів також дотримуються інші фахівці [10, 19 та ін.]. Загалом схема складається з чотирьох основних етапів: постановки завдання, формування БЗ і БД, оброблення та аналізу даних на основі використання географічних інформаційних систем (ГІС), комплексного аналізу і геологічної інтерпретації інтегрованої в ГІС інформації. Розглянемо ці етапи детальніше.

Постановка завдання. У залежності від етапу і стадії ГРР, при яких використовуються МДЗ, з допомогою розробленої технології можуть вирішуватися різні завдання:

- тектонічне районування і районування території щодо перспективності на якісь корисні копалини (інші об'єкти пошуку) з виділенням основних розломів, розривів, ділянок/площ, перспективних на виявлення якихось корисних копалин (об'єктів);

- виділення розломно-блокових полів, нафтогазо- або рудовмісних локальних структур в їхніх межах, інших об'єктів пошуку з визначенням черговості їх подальшого дослідження різними геолого-геофізичними методами і пошуковим бурінням;

- детальне вивчення перспективних площ (нафтогазо- або рудоперспективних, перспективних на пошуки різноманітних цільових об'єктів) для більш раціонального розміщення розвідувальних свердловин і виділення ділянок, де можливі ускладнення (зокрема, пов'язаних з диз'юнктивною тектонікою) при бурінні, інших гірничих роботах.

Формування бази знань. БЗ включає знання спеціалістів-експертів про предмет досліджень, методику використання та оброблення даних ДЗ3, моделі об'єктів і причинно-наслідкові зв'язки їх утворення і розвитку, які необхідні для вирішення поставлених завдань. Зокрема, БЗ для цілей розрізнення диз'юнктивних деформацій містить відомості про їхні ранги, генезис, глибини проникнення (затухання), морфокінематичні характеристики, час їх закладення, активізації, ремобілізації, особливості новітньої та сучасної активності, а також про плікативні структури і речовинні комплекси, що пов'язані з ними як просторово, так і за походженням.

БЗ для цілей прогнозу родовищ корисних копалин включає інформацію про загальні закономірності формування речовинно-структурних форм земної кори, що контролюють розподіл цих родовищ, про характер геологічного розрізу (склад, товщини, тріщинуватість гірських порід, їхні флюїдопровідні та інші фізико-хімічні характеристики), про історію тектонічного розвитку, особливо на новітньому етапі. Останнє важливо з огляду на вивчення морфології структур, що вміщують родовища корисних копалин, за МДЗ, а також їх вираженості як у ландшафті, так і на даних ДЗ3.

Необхідне виконання типізації різнорангових об'єктів пошуку (наприклад, розломів, розривних порушень вищого порядку, пасток вуглеводнів, рудовмісних зон тощо) як за геологічними ознаками, так і за ландшафтною (зокрема, геоморфологічною) і дистанційною їхньою вираженістю, ступенем неотектонічної активності. Необхідне також проведення аналізу геоіндикаційних зв'язків земного рельєфу, компонентів ландшафту загалом, рисунку зображення на МАКЗ, з одного боку, і геологічної будови - 3 іншого (див. рисунок).

Формування бази даних. БД являє собою сукупність даних, які відображають стан об'єктів досліджень та їх відношень, необхідних для 


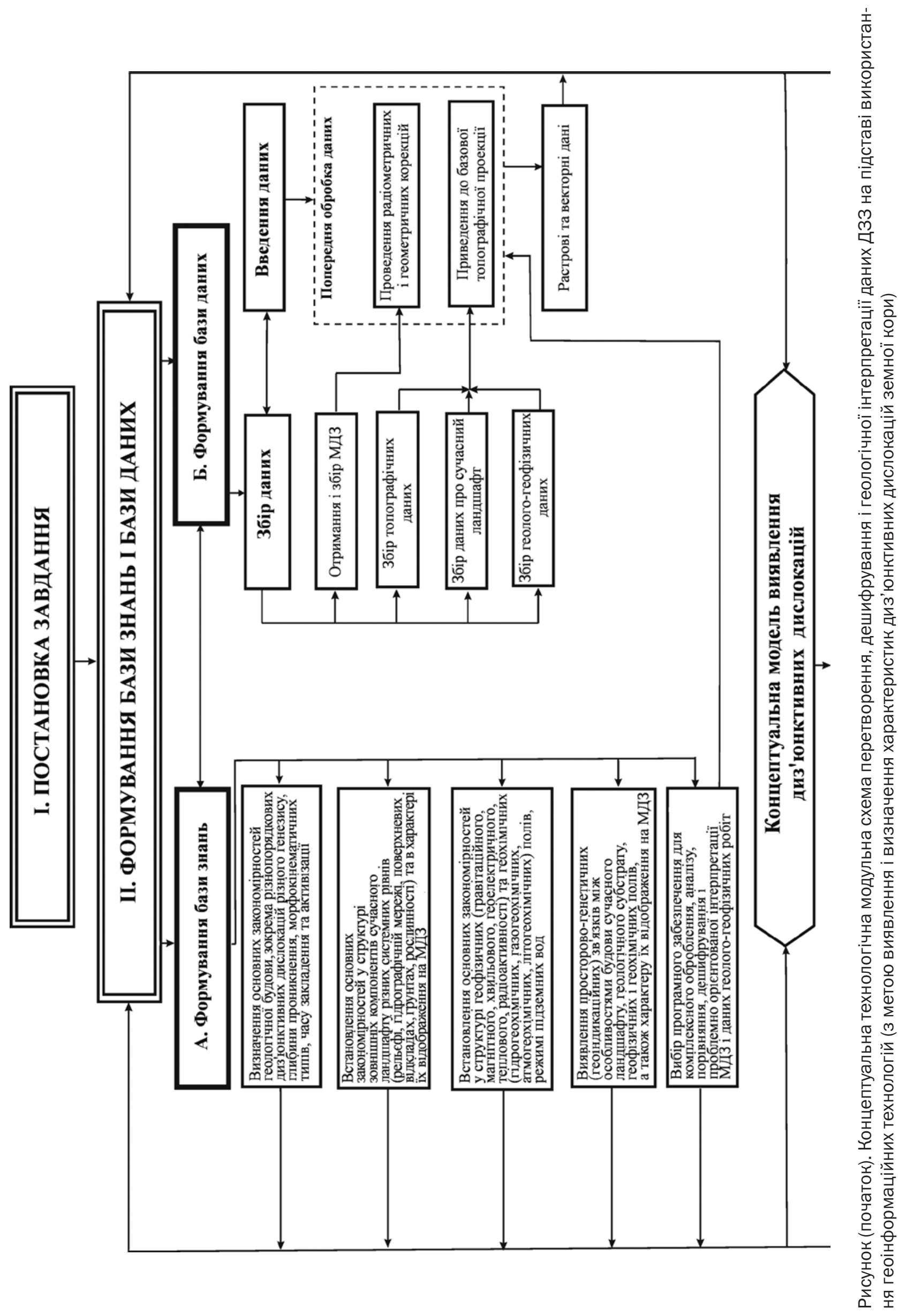




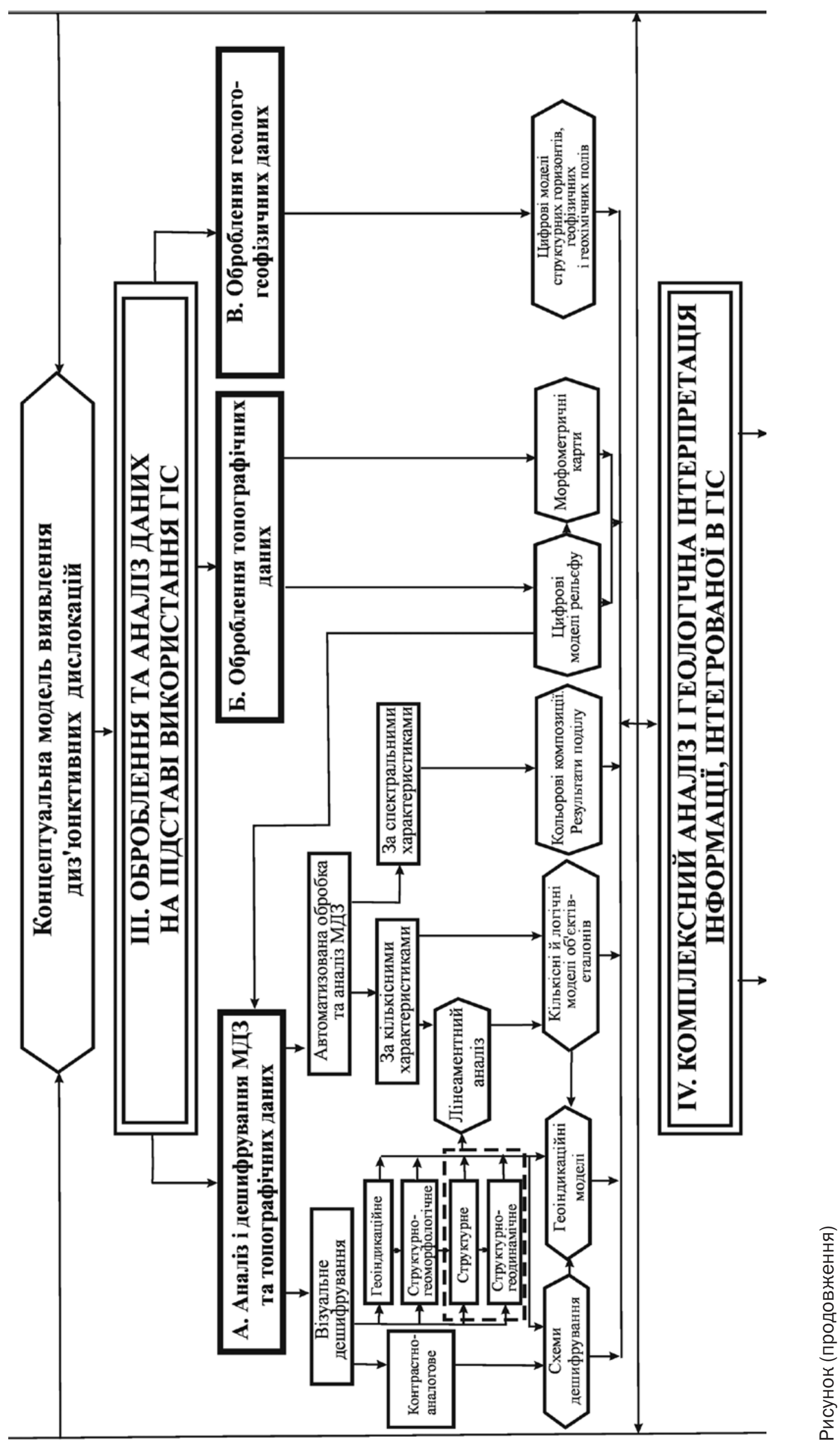




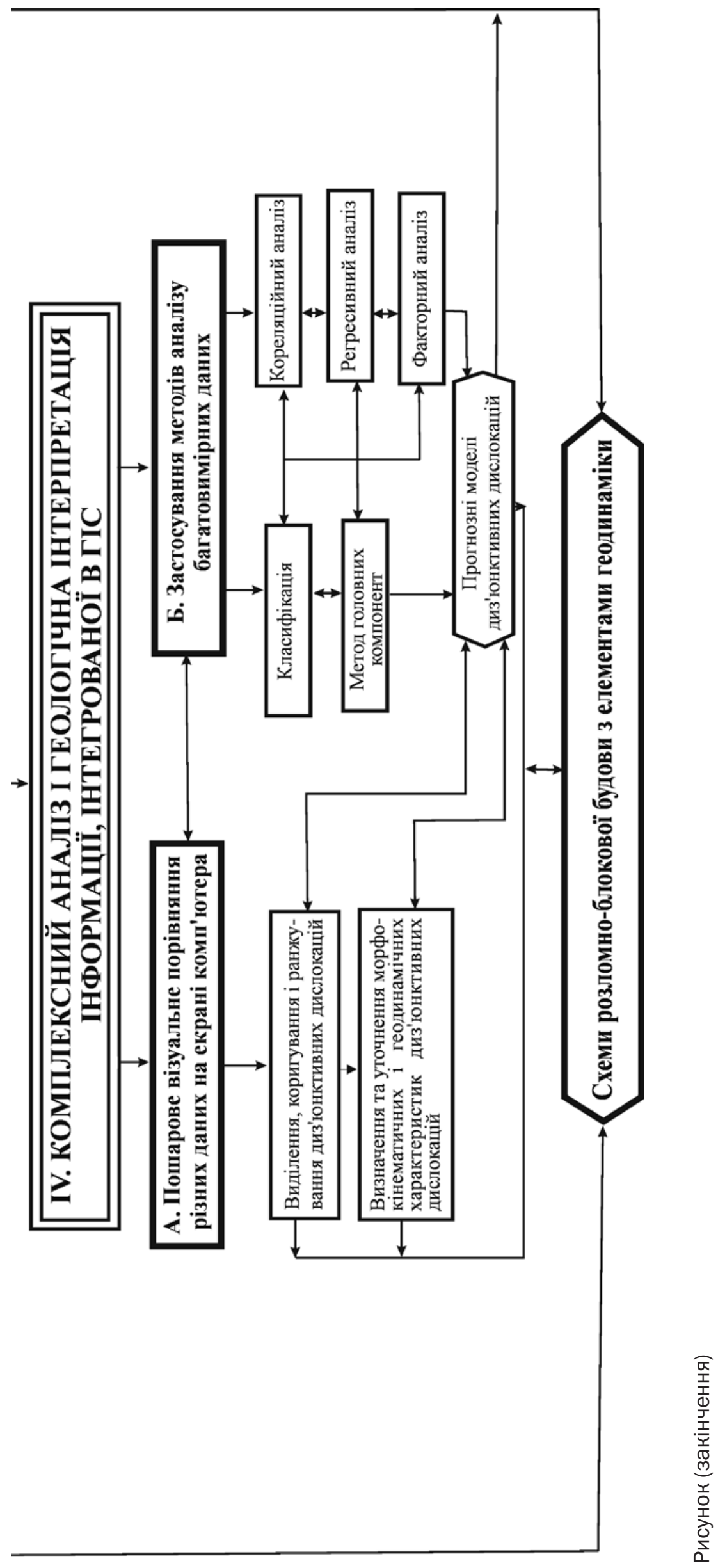


розв'язання поставлених завдань. Вона формується в залежності від змісту завдань прогнозу (пошуку) об'єктів вивчення, а також від ієрархічного рівня цих об'єктів і повинна відповідати Б3. БД загалом включає аерокосмознімальні, широкий спектр геолого-геофізичних (зокрема, геохімічні, гідрогеологічні тощо) і ландшафтних (включаючи геоморфологічні й т. п.) даних (див. рисунок). Головним чином вони подаються у вигляді картографічних матеріалів.

Доцільно складати декілька БД на одну й ту ж територію в різних масштабах. Так, для виділення регіонального розломно-блокового каркасу, прогнозування зон нафтогазонакопичення, рудоконтролюючих зон і побудови відповідних схем і карт (зокрема, тематичного районування) необхідні БД у масштабах 1:1000 000 і 1:500000, для виявлення диз'юнктивів зонального рангу, прогнозування зон розвитку і конкретних локальних нафтогазо- і рудоперспективних структур - у масштабах 1:200 000, 1:100000 і більших, для детального вивчення площ і родовищ - у масштабах 1:50000, 1:25000 і більших.

Аерокосмічні цифрові дані заносяться у БД у растровому форматі, тобто у вигляді матриці значень, що передають інформацію про яскравості або теплові властивості земної поверхні в діапазоні значень від 0 до 255 (байтове вираження). Фотозображення і картографічні матеріали уводяться з допомогою сканера й оцифровуються (векторизуються).

Загалом, чим більше (до розумної межі) геолого-геофізичної та ландшафтної інформації міститься у БД і чим вище її достовірність, тим кращою зазвичай $є$ якість моделей прогнозних об'єктів.

Концептуальні моделі об'єктів, що прогнозуються, формуються, виходячи 3 аналізу БЗ і БД. На їхній основі вибираються методи і методичні прийоми тематичного оброблення даних і відповідне програмне забезпечення для його виконання та управління БД.

Обробка та аналіз даних на підставі використання ГІС. Першою стадією аналізу $€$ візуальне дешифрування МДЗ у різних зонах спектра електромагнітних хвиль, яке проводиться для визначення найінформативніших діапазонів зйомки, побудови схем основних тектонічних елементів і схем геоморфологічного районування (див. рисунок). Ґрунтуючись на візуальному дешифруванні, аналізуються особливості відображення глибинних геологічних структур у рельєфі та на даних Д3З, виділяються розривні порушення і розділені ними блоки земної кори з різними ландшафтними характеристиками і різними типами вираженості прогнозних об'єктів, визначаються методи подальшого цифрового оброблення матеріалів.

Вже на етапі створення БЗ і БД та візуального аналізу даних починається виділення геоіндикаторів об'єктів пошуку (прогнозу): диз'юнктивні дислокації, тектонічні блоки 3 різним ступенем нафтогазо- або рудоносності, локальні, перспективні на пошуки корисних копалин, структури, окремі розриви тощо. Виділення індикаційних ознак здебільшого виконується візуально, іноді (при належних ландшафтно-геологічних умовах) і в автоматичному режимі як за вихідними дистанційними зображеннями, так і за знімками, що оброблені за спеціальними методиками, які дозволяють підсилити вираженість того або іншого геоіндикатора.

Важливою стадією оброблення багатозональних (гіперспектральних) даних дз3 $є$ аналіз відповідних знімків, який включає метод кольорових композицій, арифметичні операції з різними каналами зображень (див. рисунок). Перший з них (метод кольорових композицій) грунтується на описаному вище синтезі у псевдокольорах просторово суміщених зображень, що отримані в окремих вузьких діапазонах електромагнітного спектра та які передають яскравісні параметри природних об'єктів у цих зонах.

Методи, що використовують арифметичні операції, стосовно МАКЗ у різних зонах спектра уможливлюють, як ми зазначали, виділення тонших відмінностей у відображенні різноманітних природних утворень на зображеннях у цих зонах спектра.

Відомо, що рельєф земної поверхні є одним 3 найвагоміших геоіндикаторів глибинної структури територій. Зазвичай абсолютні відмітки рельєфу, а також геологічні (включаючи геохімічні, гідрогеологічні та ін.) та геофізичні дані подаються на картах у формі ізоліній. 3 метою інтеграції в комплексне цифрове оброблення даних їх необхідно мати (або потрібно перетворити) у форматі матриці значень. Причому це представлення (трансформування) повинно бути з кроком, який дорівнює розміру пікселя цифрового дистанційного знімка. Тобто необхідно отримати цифрову модель рельєфу денної поверхні, структурних горизонтів земної 
кори, цифрові моделі геофізичних, геохімічних полів тощо (див. рисунок).

Однією із стадій оброблення результатів дешифрування МДЗ є лінеаментний аналіз. Він належить до найефективніших методів вивчення внутрішньої будови територій. Основне його завдання в наших дослідженнях - визначення зон розломів і розривів, поділених ними блоків земної кори, що характеризуються різною просторовою організацією поля лінеаментів.

Комплексний аналіз і геологічна інтерпретація інтегрованої в ГІС інформації. Для встановлення зв'язків між моделями, що отримані на етапі оброблення даних, і глибинними геологічними структурами, а також з метою визначення найінформативніших геоіндикаторів для формування прогнозних моделей виконується комплексний аналіз інформації. Він поділяється на два підетапи. На першому на основі концептуальної моделі аналізуються окремі ознаки: вихідні дані ДзЗ, результати їх обробки, схеми геоіндикаторів та їхні характеристики. На другому аналізуються окремі схеми і моделі, що побудовані за декількома ознаками.

Комплексний аналіз інформації реалізується різними способами (див. рисунок):

- візуальним пошаровим зіставленням різних даних на екрані комп'ютера;

- методами аналізу багатовимірних даних.

Перший $з$ них (візуальне пошарове зіставленням даних на екрані комп'ютера) є найшвидшим і найпростішим способом комплексного аналізу. Він може виконуватися з допомогою будь-якої векторної ГІС. Послідовне накладання векторних шарів дозволяє виявити найзагальніші закономірності розміщення розломноблокових полів, родовищ і проявів корисних копалин, простежити вираженість прогнозних об'єктів у всіх шарах, що аналізуються. Виділені нові характеристики об'єктів, які відрізняються від концептуальних або такі, що уточнюють їх, включаються у БД і БЗ.

Методи аналізу багатовимірних даних (класифікація, головних компонент, кореляційний, регресійний, факторний аналіз тощо [10, 11, 14, 16, 19 та ін.]) застосовуються з метою оцінки структури і взаємозалежності даних, що використовуються, їхньої ролі у відображенні різнорангових геологічних об'єктів, а також 3 метою встановлення ознак для побудови моделей прогнозу або тих, що досліджуються.

\section{ОБГОВОРЕННЯ РЕЗУЛЬТАТІВ ТА ВИСНОВКИ}

Отже, як ми бачимо з викладеного вище, концептуальна технологічна схема має модульний характер. Так, у залежності від рівня завдань дослідження диз'юнктивів або інших об'єктів (глобальний, регіональний, зональний, локальний масштабні рівні), їх складності та повноти, а також від наявних дистанційних і геологогеофізичних матеріалів можуть застосовуватися окремі її модулі (складові).

Охарактеризована технологічна схема розроблена, дослідно-методично апробована і практично реалізована при дослідженні характеристик розривних порушень земної кори в умовах різної ландшафтно-геологічної будови України у рамках вирішення низки наукових і прикладних завдань надрокористування і геоекології. У подальшому є сенс цілеспрямовано модифікувати її для розв'язання актуальних проблем пошукової геології, зокрема виділення потенційних нафтогазових пасток, різноманітних рудних тіл, оцінки їх продуктивності тощо.

1. Аерокосмічні дослідження геологічного середовища: Наук.-метод. посіб. / А. Г. Мичак, В.є. Філіпович, В.Л. Приходько та ін. - К.: Мінприроди України, Держгеолслужба, 2010. - 246 с.

2. Азімов О.Т. Дослідження диз'юнктивних дислокацій земної кори аерокосмічними методами (на прикладі регіонів України): Дис. ... д-ра геол. наук: 04.00.01 "Загальна та регіональна геологія" / ІгН НАН України. — № ДО 0509U000102. - К., 2008. - 485 с.

3. Азімов О.Т. Геоінформатика у проблемі створення технологічної схеми обробки/інтерпретації даних аерокосмічних зйомок при вирішенні геологічних завдань // Матеріали IX Міжнар. наук. конф. “Моніторинг геологічних процесів" (м. Київ, 14-17 жовт. 2009 р.). К.: Вид-во КНУ ім. Тараса Шевченка, 2009. - С. 235238.

4. Азімов О. Геоінформаційні технології у концепції створення узагальненої схеми обробки/інтерпретації даних дистанційного зондування Землі // Вісн. Київ. нац. ун-ту ім. Тараса Шевченка. Геологія. - 2010. Вип. 50. - С. 37-40.

5. Азимов А.Т. Концепция создания технологической схемы обработки-дешифрирования-интерпретации данных дистанционного зондирования Земли на основе геоинформационных технологий для решения геологических задач // Учен. зап. Тавр. нац. ун-та им. В. И. Вернадского. География. - 2010. - 23 (62). № 2. - С. 22-29.

6. Азимов А.Т. Концептуальная обобщенная технологическая модульная схема преобразования, дешифрирования и интерпретации данных аэрокосмических съемок для решения тематических задач в геологии // Зб. наук. пр. X Міжнар. наук.-практ. конф. “Сучасні інформаційні технології управління екологічною безпекою, природокористуванням, заходами в надзви- 
чайних ситуаціях" (АР Крим, сел. Рибаче, 5-9 верес. 2011 р.). - К.: ВІК Принт, 2011. - С. 278-281.

7. Азимов А.Т. Создание обобщенной технологической модульной схемы обработки-интерпретации данных дистанционных съемок при решении геологических задач // Сучасні напрями геологічних досліджень в Україні: Зб. матеріалів молодіж. наук. конф. (9-10 листоп. 2011 р.). - К., 2011. - С. 9.

8. Azimov 0 . The modular flowchart of transformation, decoding and interpretation of remote sensing data (geologic objectives solving) // Archives / EAGE. http://www.earthdoc.org/detail.php?pubid=51624. 10.11.2011.

9. Аэрокосмические исследования на региональном этапе геологоразведочных работ на нефть и газ / М-во геологии СССР, ВНИГНИ; Сост. Д.М. Трофимов, Л.П. Полканова. - М.: Недра, 1988. - 160 с.

10. Аэрокосмические методы геологических исследований / Под ред. А.В. Перцова. - СПб.: Изд-во СПб картфабрики ВСЕГЕИ, 2000. - 316 с.

11. Бусыгин Б. С., Никулин С. Л., Бойко В. А. ГИС-технология поисков золота в Западном Узбекистане // Геоінформатика. - 2006. - № 1. - С. 44-49.

12. Веклич Ю.М., Целік В.В., Янцевич О.О. Розробка та вдосконалення методики геокартування та складання цифрових геологічних карт, включаючи їх дистанційну основу: Звіт про НДР 604 (заключний) / УкрДГРІ. - № ДР У-03-135/40. - К., 2005. - Кн. 1. Текст. 295 c.

13. Готынян В.С., Кострюков М.И., Лаврусь В.П. и др. Временные методические рекомендации по аэрокосмогеологическим исследованиям и использование их при нефтегазопоисковых работах. - М.: ИГиРГИ, 1987. - 158 с.

14. Дячук В. В., Лизанець А. В., Бабаєв В.В. та ін. Системний підхід до вивчення нафтогазоносних територій дистанційними методами на прикладі ДК «Укргазви- добування" // Геоінформатика. - 2002. - № 1. С. $70-76$.

15. Мичак А.Г., Філіпович В.Є., Тарангул Д. О. та ін. Розробка методичних рекомендацій 3 аерокосмогеологічних досліджень та використання їх результатів при геологорозвідувальних роботах. Звіт про НДР / ЦАКДЗ ІГН НАН України. - № ДР 0105U000753. К., 2005. - $184 \mathrm{c.}$

16. Можаев Б.Н., Афанасьев Н.Ф., Астахов В.И. и др. Геоиндикационное моделирование (с использованием материалов аэро- и космических съемок). - Л.: Недра, 1984. - 247 с.

17. Николаенко Б.А., Быстревская С.С., Воловик В.Т. и др. Карта линейных и кольцевых структур Украинской ССР (по материалам космических съемок). М-б 1:1000 000. - Киев: ЦТЭ, 1989. - 113 с.

18. Николаенко Б.А., Веремьев П.С., Кубышкина Л.К. и др. Временные методические рекомендации по применению материалов космической съемки при геологическом изучении платформенной части УССР. - Киев: ЦТЭ, 1983. - 77 с.

19. Смирнова И.О., Русанова А.А. ГИС-технология обработки и интерпретации материалов дистанционного зондирования для изучения тектонических критериев размещения месторождений углеводородов // Отеч. геология. - 1999. - № 6. - С. 32-40.

20. Чебаненко И.И., Готынян В.С., Жиловский Н.И. и др. Глубинные разломы и методика аэрокосмогеологических исследований при нефтегазопоисковых работах в ДнепровскоПрипятском авлакогене. - Киев, 1988. - 55 с. (Препр. / АН УССР. Ин-т геол. наук; 88-31 ).

Науковий Центр аерокосмічних досліджень Землі ІГН НАН України, Київ

E-mail: azimov@casre.kiev.ua

Рецензент - чл.-кор. НАН України О.Д. Федоровський 